\title{
Impact of Small-Scale Irrigation Schemes on Smallholders Household Income and Food Security in Ethiopia: Review
}

\author{
Abdulsemed Abanega Abdurahman ${ }^{1} \quad$ Ahmed Mohammed Abachebsa $^{2}$ \\ 1.Department of Agricultural Economics and Agribusiness Management, Jimma University P.O. Box. 307, \\ Jimma, Ethiopia \\ 2.Department of Natural Resource Management; Jimma University; P.O. Box. 307, Jimma, Ethiopia
}

\begin{abstract}
In Ethiopia, agriculture remains among the most important economic sectors and has been traditionally dominated for centuries by small-scale farmers. Its performance has long been adversely affected by shortage of rain and water to sustain their lives on famine relief support. From the total production of Ethiopia's, about $97 \%$ food crops are produced by rain-fed agriculture, whereas only $3 \%$ is from irrigated agriculture. On the other hand, Ethiopia has abundant water resources, but not yet fully benefited from technologies of water management and irrigation. The aim of this paper is to identify the impact of small-scale irrigation on household income and food security reviewing different literature. Different studies indicated that access to irrigation water can enable farmers to adopt new technologies and intensify cultivation, leading to increased productivity, production, and greater returns from farming. Access to irrigation enables farmer to grow crops more than once a year increasing production, income and improve their food security status. This review concludes small-scale irrigation is one of the possible solutions to increase smallholder household income and food needs in the country. But there are different challenges hindering the irrigation development by smallholder households like lack of market at the time of harvest, distance from water sources, knowledge on the efficient use of irrigation, and linkage between micro finance institutions and smallholder horticultural crop producers are some constraints. These constraints have to be solved to increase participation of stallholder household in irrigation technology to improve their living standards through this sector. Keywords: Agriculture, Ethiopia, Small scale irrigation, Water resource
\end{abstract}

DOI: $10.7176 / \mathrm{JBAH} / 11-1-05$

Publication date: January $31^{\text {st }} 2021$

\section{INTRODUCTION}

In Ethiopia, agriculture remains among the most important economic sectors. It produces about one-third of GDP and employs 70 percent of the workforce, accounting for 80 percent of the country's merchandise exports (EATA, 2014). Agriculture is the leading sector of Ethiopian economy as well the overall economic growth of the country largely depends on the agricultural sector. However, Ethiopian agriculture remains characterized by small-scale subsistence production systems where crop and livestock yields are very low(Desta and Almaz, 2015).Although agricultural productivity is very much affected due to variability of rainfall and drought(Sensen, 2013).

Even if agriculture status is the backbone of the Ethiopian economy, agricultural practice has been traditionally dominated for centuries by small-scale farmers and its performance has long been adversely affected by shortage of rain and water that left many to sustain their lives on famine relief support(Abebe et al., 2011, Temesgen et al., 2018). From the total production of Ethiopia's, about $97 \%$ food crops are produced by rain-fed agriculture, whereas only $3 \%$ is from irrigated agriculture (FAO, 2015). Because of high dependency on rain-fed agriculture, other topographic and low adaptive capacity along with other related factors, Ethiopia ranks the ninth most susceptible country in the world to natural disasters and weather related shocks (Tongul and Hobson, 2013). On the other hand, Ethiopia has abundant water resources, its agricultural system does not yet fully benefit from the technologies of water management and irrigation(Seleshi et al., 2010).

According toNahusenay and Madhu( 2015),one of the aspects given attention by the government is to improve food and agricultural production through the strengthening small scale irrigation. The net farm income is the most watched indicator of farm sector well-being, as it captures and reflects the entirety of economic activity across the range of production processes, input expenses, and marketing conditions that have persisted during a specific time period. There are different mechanisms by which irrigated agriculture can improve household income and food security, through: increasing farm production and productivity that helps very poor households meet the basic needs, protecting against risks of crop loss due to erratic, insufficient rainwater supplies, promoting greater use of yield enhancing farm inputs and creation of additional employment(Agidew, 2017).

Agricultural intensification is presumed to be a necessary pre-condition for the development of the agricultural sector in Ethiopia. To this end, various government and non-governmental organizations (NGOs), among others, initiated small-scale irrigation schemes throughout the country(Kinfe et al., 2012). The importance of small-scale irrigation for improving farmers' income and reducing rural poverty has been emphasized in various literatures and small-scale irrigation schemes play a huge role to increase income of the society(Ayana, 2016). The current Ethiopian government has undertaken various activities to expand irrigation in the country. The country's 
Agricultural Development Led Industrialization strategy considers irrigation development as a key strategy for sustainable agricultural development. Thus, irrigation development, particularly small-scale irrigation is planned to be accelerated(MoFED, 2010). The local institutions and the rural infrastructure services can improve the awareness of people regarding irrigation and he expansion of small-scale irrigation can be an important strategy to increase income, build-up assets, increase total expenditure, and spend more income on improved agricultural technologies(Woldegebrial et al., 2015).

Irrigation in Ethiopia contributes to increase farmers ${ }^{\text {ee }}$ income, household resilience and buffering livelihoods against shocks and stresses by producing higher value crops for sale at market and to harvest more than once per year. In turn, this provided them to build up their assets, buy more food and non-food household items, educate their children, and reinvest in further increasing their production by buying farm inputs or livestock. However, the benefits are very unevenly distributed among households(Eshetu et al., 2010). Therefore, the aim of this paper is to contribute literature on impact of small-scale irrigation schemes on smallholder farmers' incomes and food security and also challenges and opportunity for smallholder farmers to use irrigation in Ethiopia.

\section{Basic Concept and Definitions}

In general terms, irrigation can be defined as the artificial supply of water to supplement natural precipitation or substitute for it for the purpose of agricultural production(Mohamed, 2006). According to Indhumathi et al., (2017) Water is most powerful natural resource as it has great influences in health and wealth of the people and production of food. Thus, water has great role in survival and comfortable life of living things. We are depending on the water resources for development of agriculture. Besides various other uses of water, the largest use of water in the world is for irrigating land. The same report by $\operatorname{MoWE}(2013)$, indicated that water is a basic need for human beings and animals. It is essential for their metabolic processes. It is used to build healthy workforce, ensuring food security, provision of clean energy for agriculture and industry.

Food security is defined in different ways by different organizations around the world. For example, in 1996, the definition of food security was agreed and accepted at the world food summit in Rome and it was defined food security as a physical and economic access by all people at all times to sufficient, safe and nutritious food to meet their dietary needs and food preference for an active and healthy life(Todaro and Smith, 2011). According to FAO(2011), food security contains different features, such as food availability, accessibility, utilization and stability. Food availability refers to the existence of food from own production or on the markets. It is a combination of domestic foods production, marketable imports and food aid. Food access is guaranteed when households and all individuals within them have adequate resources, through access options. Food utilization refers to nutritional and safety aspects of food security to meet adequate diet, clean water, sanitation and health care to search a state of nutritional wellbeing. Food stability complements the previous factors by stressing that food must be available, accessible, affordable and properly utilized on a continuous basis.

\section{History of Irrigation development and participation condition in Ethiopia}

Ethiopia has a long history of traditional irrigation systems. Simple river diversion still is the dominant irrigation system in Ethiopia. According to Seleshi et al. (2010), estimates the irrigation potential of Ethiopia may be as large as 4.3 million hectares. Traditional irrigation schemes cover more than 138,000 hectares whereas modern small-scale irrigation covers about 48,000 hectares. The total current irrigation covers only about $6 \%$ of the estimated potential land area.

According to Gebremedhin and Asfaw( 2015), irrigation was practiced during ancient times in Ethiopia even if its exact date of emergence is unknown. Ancient use of irrigation water was through use of surface irrigation methods and spate irrigation types. Modern irrigation was started at the Awash River basin with bilateral cooperation of Ethiopia and Dutch company. Ethiopia is a rich country in water resource and most of the time it is termed as a water tower of east Africa because of its abundant water resource availability(Adugna , 2014). Although Ethiopia has a huge potential of water resource which accounts 122 billion meter cube annual surface runoff and 2.9 billion meter cube groundwater, it is characterized by uneven spatial and temporal distributions(Tesfa, 2015). But, Ethiopia is using a very little of its abundant water resource potential for irrigated agriculture(ATA, 2016). The study taken by Gebremedhin (2015), indicated that the policies and strategies of Ethiopia strongly supports the irrigation developments especially the small scale irrigation through the Water Sector Development Programs (WSDP) and Ethiopian Irrigation Development Plan (IDP). This irrigation development is mainly expressed in the development of small-scale irrigation schemes by governments, donors and NGOs. Irrigation is believed as a key for food security and poverty reduction in Ethiopia. As a result, developments in the Ethiopian irrigation system have shown great advancements so as to assure Ethiopian livelihoods especially in the rural areas. However, the contribution of irrigation to the national economy as compared to its potentials is insignificant(Woldegebrial et al., 2017). 


\section{Impacts of Small-scale Irrigation on income and Food Security in Ethiopia}

Access to such small scale irrigation can significantly improve income level and food security status of beneficiary households(Eshetu and Young-Bohk, 2017). According to Lipton et al. (2003), irrigation increases productivity by reducing crop losses that were due to limited water supply, enabling cultivation during the lean season, and making crop production possible on lands where rain fed agriculture is infeasible. The other study shows that farm productivity is positively correlated with the availability of farm power coupled with efficient farm implements and their sustainable utilization. On the other hand the report of (MoA, 2015) shows that Agricultural mechanization not only enables efficient utilization of various inputs such as seeds, fertilizers, plant protection chemicals and water for irrigation but also it helps in poverty alleviation by making farming an attractive enterprise. In Ethiopia, nearly all small farmers are still using traditional hand tools and oxen plow, which greatly is restricting crop productivity and production.

Irrigated agriculture plays a central and dynamic role in the improvement of rural livelihoods, but is often subject to criticisms of inefficiency in water use, high capital and recurrent costs and lack of sustainability associated with inequity in the distribution of both land and water(Reinders, 2011). Although irrigation leads to increased agricultural income and production diversity, and this leads to improved diets and access to irrigation has the potential to improve both household income and the diversity of crops that farmers produce. Increasing household income, in turn, leads to higher dietary diversity, while increases in production diversity do not contribute to increases in dietary diversity over and above the effect of income (Passarelli et al., 2018).

According to Garbero and Songsermsawas (2018), Small-scale farmers in the developing world face multiple challenges that limit their opportunities to achieve higher agricultural productivity and improve their living conditions. One promising channel to help farmers attain more desirable agricultural outcomes is to increase their access to water, an important input for agricultural activities. Several studies have noted the positive and significant benefits of irrigation infrastructure on agriculture. Although, small-scale irrigation development has a positive impact on food security status of rural households and a much higher proportion of those who are poor are nonirrigating rather than irrigating households. Thus, the food insecurity occurrence in non-irrigating households is greater than in irrigating households1(Muez, 2014). The main income sources of Ethiopian rural households were cropping, livestock and off-farm activities and the irrigating households have significantly larger mean annual income than non-irrigating households. Although the poverty analysis indicated that a much higher proportion of poor are non-irrigating than irrigating households, different studies revealed that there is positive significant impact on the income of participant household income as a result of participation in small-scale irrigation(Getaneh, 2011; Temesgen et al., 2018).

According to Awulachew (2010), with high potential, if it is successfully operated, irrigation in Ethiopia could play a significant role in the agricultural transformation of the country, contributing up to ETB 140 billion to the economy. Furthermore, another study done by Tsegazeab (2015) micro irrigation is one of the most useful irrigation systems designed to increase production and productivity; and reduces risk, related with rainfall variability and increases income of rural farm households and not surprisingly, planners, researchers, development practitioners, and donors emphasize the importance of micro irrigation in their policy recommendations and actual measures.

According to Aam (2013), small-scale irrigation has immense potential to improve agricultural productivity and incomes of poor rural households. Irrigation in fact is nothing but is a continuous and reliable water supply to different crops in accordance with their water requirement. According to Seleshi et al.(2005), agricultural production in Ethiopia has affected by increasing population, deforestation and land distribution. This reflected in a decrease in household production and grazing land. Hence, it has become a common phenomenon to ask for emergency food assistance for acutely food insecure people in Ethiopia. The adoption of new technology (e.g. irrigation) is the major powerful for agricultural growth and poverty reduction(Norton et al., 2010). This indicates that investment in irrigation can increase farmer's independence on rainfall, it increases irrigated farmland, it generates employment, it promotes farmers to produce two or three times in a year and use more of chemical inputs. Small scale irrigation in developing countries was considered as a means of increasing production, reducing the dependence on rainfall and provides jobs to the poor(Chazovachii, 2012).

Although small-scale irrigation is believed in helping to address irregular rainfall pattern problem there by reducing rural poverty, food insecurity as well as improving the overall contribution of agriculture to the national economy(Tizita, 2017), it increases land productivity, crop yields, adoption of mineral fertilizers and enables to diversify into non-conventional and market-oriented products (Eshetu et al., 2010). It also improves farm households"e diet, incomes, health and food security(Torell and Ward, 2010). Hence irrigated agriculture is accepted as essential in increasing land productivity, enhancing food security, earning higher and more stable incomes and increasing for multiple cropping and crop diversification(Smith, 2004). Access to irrigation positively and significantly affects household food security and irrigation user households were more likely to be food secure as compared to irrigation non-users, holding other variables constant. This implies that irrigation enables households to grow food crops more than once a year, hence increased production, income and food availability 
of the household(Tizita., 2017).

Although irrigation expansion has been regarded as a promising approach to ensure food and livelihood security in the face of climate change and population growth while only $4 \%$ of cultivated area in sub-Saharan Africa is currently irrigated, the potential for the expansion of irrigation in the region is large and investments are accelerating(Giordano et al., 2012). Previous investments in irrigation by donors and governments have focused on developing large scale irrigation schemes, but evidence suggests that the greatest gains in terms of profitability and sustainability will come from investments in small scale irrigation (Xie et al., 2014).

In general irrigation in Ethiopia is considered as a basic strategy to alleviate poverty and reduce food security. It is useful to transform the rain-fed agricultural system which depends on rainfall into the combined rain-fed and irrigation agricultural system. This is believed to be the most prominent way of sustainable development in the country. However, the development of irrigation practices in Ethiopia has to be investigated so as to seriously know the history of irrigation emergence and its subsequent developments(Gebremedhin, 2015).

\section{Challenges and Opportunities of Irrigation Development in Ethiopia}

There are different challenges that hinder the irrigation development by small holder households in Ethiopia. According to Temesgen (2017), out of the challenges pointed out by farmers, lack of market at the time of harvest holds the first rank, distance of farm land from irrigation water source, lack of knowledge on the efficient use of irrigation by the farmers, lack of market and linkage, lack of awareness on the sustainable use of water and lack of linkage between micro finance institutions and smallholder horticultural crop producers are some constraints. Although the major small-scale irrigation problems identified by different studies throughout the country indicated that, financial constraints especially for the purchase of motor pumps, shortage of agricultural inputs specially improved seed and pesticides, high cost of irrigation, shortage of water pump technologies, spare parts and gabions, technical problems such as maintenance of motor pumps, insufficient market information and market networks, shortage of ponds and diversion, infrastructure specially road and storage, theft of fruits, diseases and pests such as rust, root ruts, ball worm, blights, powdery mildew, gummosis and water borne diseases are among the problems (Nahusenay and Madhu, 2015).

Another study taken by Gebremedhin and Asfaw (2015), identified the challenges for Ethiopian irrigation development are: Inadequate awareness of irrigation water management as in irrigation scheduling techniques, water saving irrigation technologies, water measurement techniques, operation and maintenance of irrigation facilities, inadequate knowledge on improved and diversified irrigation agronomic practices, shortage of basic technical knowledge on irrigation pumps, drip irrigation system, sprinkler irrigations, surface and spate irrigation methods, inadequate baseline data and information on the development of water resources, lack of experience in design, construction and supervision of quality irrigation projects, low productivity of existing irrigation schemes, inadequate community involvement and consultation in scheme planning, construction and implementation of irrigation development and poor economic background of users for irrigation, infrastructure development are some challenges. Another study taken by Tizita(2017) shows that lack of suitable land that can be used for irrigation (irrigable farm land) was the major constraints for irrigation non-user households.

On the other hand, there are many opportunities that enhance irrigation development in Ethiopia. From these opportunities the policies and strategies of Ethiopia strongly supports the irrigation developments(Tadesse and Baihilu, 2017). Another study taken by Amede(2014), identified the following future opportunities: high water potential, high commitment of the Ethiopia government, donors and NGOs to support irrigation management and development activity. There is also availability of favorable climate condition and ground water in Ethiopia. It can be used as an opportunity to produce more than once a year if the farmers could be able to access the ground water by means of using different types small-scale irrigation (Temesgen, 2017).

\section{Conclusions}

Irrigation plays an important role in the performance of agriculture and improvement of rural livelihoods which increases income from agriculture sector and reduce the risk of crop failure as a result of erratic rainfall. It increases farm production and productivity that helps poor households to meet the basic needs, protecting against risks of crop loss due to erratic, unreliable or insufficient rainwater supplies, promote greater use of yield enhancing farm inputs and create additional employment. Also, small-scale irrigation development has a positive impact on food security status of rural households and a much higher proportion of those who are poor are non-irrigating rather than irrigating households. Ethiopia is a rich country in water resource, but using a very little of its abundant water resource potential for irrigated agriculture. While investment in irrigation can increase farmer's independence on rainfall, it increases irrigated farmland, generates employment, promotes farmers to produce two or three times in a year and use more of chemical inputs.

There are different challenges that hinder the irrigation development by small holder households in Ethiopia. Out of these challenges written in different papers, lack of market at the time of harvest holds, distance of farm land from irrigation water source, lack of knowledge on the efficient use of irrigation by the farmers, lack of market 
and linkage, lack of awareness on the sustainable use of water and lack of linkage between micro finance institutions, smallholder horticultural crop producers, shortage of agricultural inputs specially improved seed and pesticides, high cost of irrigation, shortage of water pump technologies and infrastructure specially road and storage are some constraints. On the other hand, there are different opportunities that increase irrigation development in Ethiopia. i.e. High-water potential, effective utilization of small-scale irrigation scheme infrastructure through diversification of uses to meet various needs for water such as domestic, irrigation, the interest of development agencies to give education and training, policies and strategies of Ethiopia strongly supports the irrigation developments.

In general irrigation have a great role in economic development and in increments of food security and Ethiopia has high potential of water resource that can help irrigation development from African countries but, still she didn't use this potential efficiently and the various actors of this sectors have to give attention to utilize this resource efficiently.

\section{References}

Aam O. (2013). The Influence of Ndanda Traditional Irrigation Scheme on Crop Productivity In Masasi District. Sokoine University.

Abebe, E., Bihon K \& Y, G. (2011). Determinants of Land Allocation to Irrigation and its Wealth Effect: Evidence from Northern Ethiopia. Journal of the Drylands 4, 310-319.

Adugna E. (2014). Five Key Constraints To Small-Scale Irrigation Development in Ethiopia, Socioeconomic View: Review Paper. Global Advanced Research Journal of Management and Business Studies, 3, 441-444.

Agidew A. (2017). The Determinants of Small-Scale Irrigation Practice and its Contribution on Household farm Income: The Case of Arba Minch Zuria Woreda, Southern Ethiopia. African Journal of Agricultural Research, $12,1136-1143$.

Amede T. (2014). 'Technical and Institutional Attributes Constraining the Performance of Small-Scale Irrigation in Ethiopia', 2014. Water Resour. Rural Dev. Homepage Www. Elsevier.Com/Locate/Wrr,.

ATA(Agricultural Transformation Agency) (2016). Annual Report. Addis Ababa, Ethiopia.

Awulachew S. (2010). Irrigation Potential in Ethiopia Constraints and Opportunities for Enhancing the System. International Water Management Institute.

Ayana A. (2016). Assessing The Impact of Small-Scale Irrigation Schemes on Household Income in Bahir Dar Zuria Woreda, Ethiopia. Journal of Economics and Sustainable Development, 7.

Chazovachii, B. (2012). The Impact of Small Scale Irrigation Schemes on Rural Livelihoods: the Case of Panganai Irrigation Scheme Bikita District Zimbabwe. Journal of Sustainable Development In Africa, 14, $217-231$.

Desta, D. \& Almaz, B. (2015). Review on Impact of Small Scale Irrigations in Household Food Security in Ethiopia. Journal of Economics and Sustainable Development, 6.

EATA(Ethiopian Agricultural Transformation Agency) (2014). Annual Report 2013/14. Transforming Agriculture In Ethiopia.

Eshetu, S., Belete, B., Goshu, D. \& Kassa, B. (2010). Income Diversification Through Improved Irrigation In Ethiopia: Impacts, Constraints and Rospects for Poverty Reduction. Evidence From East Harerghe Zone, Oromia Region, Ethiopia. Overseas Development Institute, Research Inspired Policy and Practice Learning in Ethiopia and The Nile Region (Ripple), Working Paper 14, Ethiopia.

Eshetu, T. \& Young-Bohk, C. (2017). Contribution of Small Scale Irrigation to Households' Income And Food Security: Evidence from Ketar Irrigation Scheme, Arsi Zone, Oromiya Region, Ethiopia. African Journal of Business Management, 11, 57-68.

FAO (2011). The State of Food Insecurity in The World. How Does International Price Volatility Affect Domestic Economies A Food Security?

FAO (2015). Ethiopia Country Highlights on Irrigation Market Brief. . Unfao, Rome, Itally. Prepared Under Food and Agricultural Organization of United Nations(Unfao)/International Finance Corporation(Ifc) Cooperation.

Garbero, A. \& Songsermsawas, T. (2018). Impact of Modern Irrigation on Household Production and Welfare Outcomes. International Fund for Agricultural Development (Ifad) Research Series, 31.

Gebremedhin, G. \& Asfaw, K. (2015). Irrigation In Ethiopia: A Review. Academia Journal of Agricultural Research, 3, 264-269.

Gebremedhin G. (2015). Irrigation In Ethiopia, A Review. Journal of Environment and Earth Science, 5.

Getaneh K. (2011). The Impact of Selected Small-Scale Irrigation Schemes on Household Income and The Likelihood of Poverty In The Lake Tana Basin of Ethiopia. Master of Professional Studies, Cornell University.

Giordano, M., De Fraiture, C., Weight, E. \& Van Der Bliek, J. (2012). Water For Wealth and food Security:Supporting Farmerdriven Investments in Agricultural Water Management. Synthesis Report of The Agwater Solutions Project. International Water Management Institute.

Indhumathi, G., C. Suresh \& Sangeetha, M. (2017). A Study on Modern Techniques Used In Irrigation For Farming In Coimbatore City. International Journal of Interdisciplinary Research In Arts And Humanities 
(Ijirah), 2.

Kinfe, A., Chilot Y. \& R., S. (2012). Effect of Small-Scale Irrigation on The Income of Rural Farm Households: The Case of Laelay Maichew District, Central Tigray, Ethiopia. The Journal Of Agricultural Sciences, 7.

Lipton, M., Litchfield, J. \& Faurès, J. (2003). The Effects of Irrigation on Poverty. A Framework For Analysis. Water Policy, 5, 413-427.

MoA(Ministry of Agriculture) (2015). Agricultural Growth Program Ii Program Design Document. Addis Ababa.

MoFED (Ministry of Finance and Economic Development)2010. The Federal Democratic Republic of Ethiopia. Growth and Transformation Plan (Gtp) 2010/11-2014/15. September 2010, Addis Ababa, Ethiopia.

Mohamed B. (2006). Overview of The Hystory of Water Resources and Irrigation Management In The Near East Region. 1st Iwa International Symposium on Water and Wastewater Technologies In Ancient Civilizations.

MoWE(Ministry of water and Energy) (2013). Water Resources Management and Irrigation Policy. In: Annual Report of Mowe, A., Ethiopia. Http://Www.Mowr.Gov.E. (Ed.).

Muez H. (2014). The Impact of Small-Scale Irrigation on Rural Household Food Security (The Case of Emba Alaje Woreda). Mekelle, Ethiopia.

Nahusenay, T. \& Madhu, S. (2015). Opportunities and Challenges of Small-Scale Irrigation and Its Implications For Livelihood Improvement: (The Case of Tigray Regional State, Northern Ethiopia). Journal of Business Management \& Social Sciences Research 4.

Norton, G., Alwang, J. \& Masters, W. (2010). Economics of Agricultural Development World Food Systems and Resource Use. 2ndedition.

Passarelli, S., Dawit, M., Elizabeth, B. \& Ringler, C. (2018). Evaluating The Pathways From Small-Scale Irrigation to Dietary Diversity: Evidence from Ethiopia and Tanzania. The Science, Sociology And Economics of Food Production and Access to Food. Published In Cooperation With The International Society For Plant Pathology (Ispp), 10, 981-997.

Reinders, F. B. (2011). Irrigation Methods for Efficient Water Application: 40 Years of South African Researh Excellence. Water Sa 37 (5), 122-127.

Seleshi, B., Merrey, A., Kamara, B., Koppen, F. \& Boelee, E. (2005). Experiences and Opportunities for Promoting Small Scale/Micro Irrigation and Rainwater Harvesting for Food Security In Ethiopia. Addis Ababa: Iwrm.

Seleshi , B., Teklu, E. \& Regassa, E. (2010). Irrigation Potential In Ethiopia; Constraints and Opportunities For Enhancing The System. International Water Management Institute,. Addis Ababa, Ethiopia.

Sensen H. (2013). The Impact of Community Managed Irrigation on Household Income and Poverty Reduction (The Case of Seharti Samre Wereda, Tigray, Ethiopia). Mekelle

Smith, L. (2004). Assessment of The Contribution of Irrigation to Poverty Reduction and Sustainable Livelihoods. Int. J. Water Resourc. Dev. , 20, 243-257.

Tadesse, M. \& Baihilu, B. (2017). Review on Participatory Small-Scale Irrigation Schemes and Small-Scale Rainwater Harvesting Technology Development and its Contribution to Household food Security In Ethiopia. International Journal of Water Resources and Environmental Engineering, 9, 54-63.

Temesgen, H., ., Mengistu, K., . \& Fekadu, B., . (2018). Evaluating The Impact of Small-Scale Irrigation Practice on Household Income In Abay Chomen District of Oromia National Regional State, Ethiopia. Journal of Development and Agricultural Economics, 10, 384-393.

Temesgen H. (2017). Participation In and Impact of Small-Scale Irrigation Practice on Household Income: The Case of Abay Chomen District of Oromia National Regional State, Ethiopia Msc Thesis Temesgen Hirko Lebeta August 2017. Haramaya University.

Tesfa W. (2015). Watershed Management in Highlands of Ethiopia: A Review. Open Access Library Journal, 2, $1-11$.

Tizita D. (2017). The Effect of Small Scale Irrigation on Household food Security in Bona-Zuria Woreda, Sidama Zone, Southern Ethiopia.

Todaro, M. \& Smith, S. (2011). Economic Development.

Tongul, H. \& Hobson, M. (2013). Scaling up an Integrated Watershed Management Approach Through Social Protection Programmes In Ethiopia: The Meret and Psnp Schemes. Hunger, Nutrition, Climate Justice.

Torell, G. \& Ward, F. (2010). Improved Water Institutions for food Security and Rural Livelihoods in Afghanistan 'eS Balkh River Basin. Water Resources Development, 26, 613-637.

Tsegazeab G. (2015). Adoption and Impact of Micro Irrigation on Households Income: The Case of Bambasi Woreda. Research and Knowledge Management of St. Mary’s University, 86-96.

Woldegebrial, Z., Assefa, H. \& Gebresilassie, H. (2017). Adoption of Irrigation and its Consequences on Household Income in The Northern Ethiopia Journal of Environmental Studies \& Management, 10.

Woldegebrial, Z., Guido V., Assefa H., M. G. Ch. \& S., S. (2015). Irrigation and Drainage. Adoption of SmallScale Irrigation and its Livelihood Impacts in Northern Ethiopia Mekelle University, Mekelle, Ethiopia.

Xie, H., You, L., Wielgosz, B. \& Ringler, C. (2014). Estimating The Potential for Expanding Smallholder Irrigation In Sub-Saharanafrica. Agricultural Water Management, 131. 